\title{
Identification of the Influence of Leadership and Organizational Culture on Employee Discipline
}

\author{
Yuki Fitria ${ }^{1}$, Sutiyem Sutiyem ${ }^{2}$, Dessy Trismiyanti ${ }^{3}$, Suhery Suhery ${ }^{4}$ \\ ${ }^{1}$ Universitas Negeri Padang, Padang, Indonesia, $\square$ yuki.fifit@gmail.com \\ 2STIE Perdagangan Padang, Padang, Indonesia, $\bowtie$ Iyeksurti240140@gmail.com \\ 3STIE Perdagangan Padang, Padang, Indonesia, $\square$ dessytrismiyanti123@gmail.com \\ ${ }^{4}$ STIE Perdagangan Padang, Padang, Indonesia, $\square$ suheriasia@gmail.com
}

\begin{abstract}
The objective of this study is to determine the effect of leadership and organizational culture on employee discipline at BAPD in West Pasaman regency. This study used total sampling technique. The numbers of sample in this study were 82 respondens. The type of data used was the primary data obtained from the questionnaires that were distributed to the respondents. The data were analyzed by using simple linear regression analysis. Based on the analysis, the results of this study supported the hypotheses: leadership has positive and significant effect on employee discipline, with sig. $0.006<0.05$; and organizational culture has positive and significant effect on employee discipline, with sig. $0.000<0.05$.

Keywords: employee disciplince, leadership, organizational culture
\end{abstract}

\section{Introduction}

The rapid development in this era requires every company, institution, or organization to go ahead and keep up with the changes that occur, especially in managing and improving their human resources. Human resource is one of the important assets in the activities of a company. The center for every strategy for resource use is organizational employee. Employees play a major role in carrying out work in a company, because no matter how advanced a technology is, in practice in order to move or control these tools human resources are needed, especially quality human resources. Schultz in M. Luhung and Beny (2016) suggests that the factors that determine the quality of human resources are intelligence level, talent, personality traits, education level, work ethic, and work discipline.

Work discipline according to Gouzali (2000) is the attitude and behavior of an employee manifested in the form of his/her willingness with full awareness, and sincere sincerity or without coercion to obey and implement all company regulations and policies in carrying out his/her duties and responsibilities in an effort to contribute maximally in achieving company goals. According to Singodimedjo in Sutrisno (2010) work discipline is someone's attitude of being ready and willing to obey and comply with the rules and regulations that apply around him/her. Thus it can be said that work discipline is a consistent behavior that shows a willingness to obey and comply in an orderly manner with regulations in an effort to improve the quality and performance of the organization.

Discipline is the most important operative function of Human Resource Management (HRM) because the better the discipline of employees is, the higher the work performance can be achieved. Good discipline reflects the magnitude of one's responsibility for the tasks assigned to him/her. Employee's work discipline also shows his/her respectful condition or attitude on the rules and regulations in the company. Thus, if the rules or provisions in the company are ignored or often violated, it means that the employees have poor work discipline. Therefore, good work discipline will be a useful advantage, both for the company and for the employees themselves (Widya and Romat, 2017).

Given the importance of work discipline of employees, it is necessary to know the factors that can improve work discipline of employees. According to Susilo (2007) the factors that influence work discipline of employees include motivation, education and training, leadership, welfare and discipline enforcement. Meanwhile, Pratiwiningsih (2006) states that the factors of salary, leadership, motivation, and communication affect work discipline of employees. In addition, Erawati (2007) 
states that organizational culture, leadership, and compensation have an effect on work discipline of employees.

The enforcement of employee discipline in an organization is inseparable from the role of a leader. A leader in an organization can create harmonious integration and encourage work passion of employees in order to achieve goals maximally. A leader is someone who uses authority, directs employees to work on their part of work in order to achieve organizational goals. Meanwhile, leadership is a leadership style or manner that is brought by a leader in influencing the followers (Wursanto, 2005). Thus it can be said that leadership is a way of a leader in directing, encouraging and regulating all the elements in the group or organization to achieve the desired organizational goals so that maximum employee performance can be yielded (Jeli, 2017).

Timple in Umar (2004) states that a leader is a person who applies principles and techniques that ensure motivation, discipline, and productivity when working with other people, tasks, and situations in order to achieve company goals. It is in line with the idea of Siswanto (2002) that the development of employee discipline can be achieved when the leader can be a role model for the employees: in the front he/she always becomes a good model; in the side he/she always arouses spirit and enthusiasm for work; and at the back he/she acts as a motivator. Therefore, if a company wants to develop employee discipline to come on time, then the manager should come on time with full consequences.

Hasibuan (2012) argues that every leader is considered effective in his/her leadership if his/her employees are well disciplined. In addition, a study conducted by Jeli (2017) successfully proved that leadership has a significantly positive effect on employee discipline. Thus, leadership can strengthen the enforcement of employee discipline.

Another factor that can influence the enforcement of employee discipline is organizational culture. According to Robbins (2010), employee discipline is a consistent behavior that is done repeatedly so that a habitual pattern is formed. The patterned behavior and habits then form a culture. A behavior pattern or work habits that is accustomed in an organization is called organizational culture. Organizational culture is the values, principles, traditions and ways of working that are shared by members of an organization and influence the way they act. Organizational culture identifies its members to behave according to the principles and values of the organization. If the principles and values of the company can be interpreted and understood by members of the organization properly and correctly, then the behavior will be realized in line with the principles of organizational values, so good work discipline behavior appears on the members of the organization.

Denison and Mishra (1995) in M.Luhung and Beny (2016) suggest that organizational culture provides an identity to members of an organization as part of the organization. Organizational culture will form values, mindset and habits that are not individual. It forms behavior that directs a person to adapt to work effectively in accordance with company standards, and provides a strong identity collectively to the members of organization. Thus, organizational culture will form the values that direct someone to work according to company standards and it is one of the forms of discipline attitude and behavior.

Some previous studies could prove that organizational culture influences work discipline. A study conducted by Brahmasari and Siregar (2009), regarding the relationship between organizational culture and work discipline, found that organizational culture applied by the employees had an influence on their increasing attitude and behavior of discipline. Furthermore, a study conducted by M. Luhung and Benny (2016) could also prove that there is a significant relationship between organizational culture and work discipline. Thus, organizational culture will communicate how members of the organization should behave so that collective mindset and habits are formed and it can direct individuals to work according to company standards as a form of discipline attitude and behavior.

Based on Undang-Undang No. 43 1999, the position and role of civil servants is as an element of the state apparatus that organizes government and development in order to achieve national development goals. For this reason, the smooth running of government and the accomplishment of 
development are still very dependent on the perfection of the apparatus. The improvement of the smooth execution of duties and obligations as state apparatus has been regulated in UU No. 431999 Pasal 30 which states that in order to maintain discipline and smooth execution of duties, there is a code of ethics-disciplinary regulations of civil servants that regulate obligations, prohibitions and sanctions if the employees do not obey the rules. In relation to the aforementioned statement, one of the important aspects that need to be considered in an effort to improve the quality of human resources is to improve employee discipline. Regardless of the ability possessed by humans or employees, but if it is not balanced with an understanding of high work discipline, the work assignments that they carry out will not result in good results, and may even lead to failure in achieving organizational goals.

Employee discipline is one of the efforts that must be done in an organization, like what has been done by the Regional Assets and Revenue Agency (BAPD) of West Pasaman regency. As one of the government institutions, BAPD of West Pasaman regency has participated in running the government and development in order to achieve national development goals. So, in order to realize the achievement of organizational goals, it needs to be supported by employees with a high level of work discipline.

However, based on observations carried out at Regional Assets and Revenue Agency (BAPD) of West Pasaman regency, the level of employee discipline that has run so far has not been optimal. In connection with the process of carrying out work, there were still employees who were undisciplined at work time, did not sign employee presence, were late for work, did not attend morning gathering, and did not complete their work according to the standard and the predetermined time. The low work discipline of employees of the Regional Assets and Revenue Agency (BAPD) of West Pasaman regency could be seen from the presence and absence of the employees, as shown in the following table:

Table 1 The Absence Rate of Employees of Regional Assets and Revenue Agency (BAPD) of West Pasaman from Januari to Oktober 2018

\begin{tabular}{lcccc}
\hline Month & $\begin{array}{c}\text { The } \\
\text { Number of } \\
\text { Employees } \\
\mathbf{( 1 )}\end{array}$ & $\begin{array}{c}\text { Work } \\
\text { day } \\
\mathbf{( 2 )}\end{array}$ & $\begin{array}{c}\text { The Number of } \\
\text { Employees who did } \\
\text { not Attend Morning } \\
\text { Gathering } \\
\mathbf{( 3 )}\end{array}$ & $\begin{array}{c}\text { The Absence Rate } \\
\mathbf{( 4 )}\end{array}$ \\
\hline January & 82 & 22 & 173 & $9.59 \%$ \\
\hline February & 82 & 19 & 159 & $10.21 \%$ \\
\hline March & 81 & 21 & 73 & $4.29 \%$ \\
\hline April & 80 & 21 & 137 & $8.15 \%$ \\
\hline May & 80 & 20 & 72 & $4.5 \%$ \\
\hline June & 79 & 11 & 122 & $6.12 \%$ \\
\hline July & 78 & 22 & 105 & $4.82 \%$ \\
\hline August & 78 & 21 & 79 & $4.99 \%$ \\
\hline September & 79 & 19 & 75 & $4.62 \%$ \\
\hline October & 79 & 23 & 84 & \\
\hline
\end{tabular}

Source: Secondary Data Regional Assets and Revenue Agency (2018)

Based on Table 1 above, it can be seen that the absence rate of employees fluctuated, but the trend of the absence rate was increasing. The highest absence rate occurred in June 2018 (14.04\%) and the lowest absence rate occurred in March 2018 (4.29\%). The standard of absence set by the Regional Assets and Revenue Agency (BAPD) of West Pasaman regency is $5 \%$ per year or $0.4 \%$ per month. So it can be concluded that BAPD employee discipline has not been optimal.

Based on the elaboration of the background of the problem above, the purposes of this study are to know and to analyze: 1) the effect of leadership on employee discipline at the Regional Assets and 
Revenue Agency (BAPD) of West Pasaman regency; 2) the effect of organizational culture on employee discipline at the Regional Assets and Revenue Agency (BAPD) of West Pasaman regency.

\section{Work Discipline}

Discipline comes from Latin, namely diciplina which means practice or education, politeness and spirituality and character development. Work discipline according to Rivai (2005) is a device used by a manager to communicate with employees so that they are willing to change behavior and as an effort to increase one's awareness and willingness to comply with all company regulations and the prevailing social norms. Hasibuan (2006) argues that work discipline is a person's awareness and willingness to comply with all prevailing company regulations and social norms.

Robbins (2010) explains that work discipline is a compliance in carrying out work in accordance with company rules and standards. It is in line with the idea of Helmi (1996) in M. Luhung and Benny (2016) that work discipline is a person's attitude and behavior to comply with organizational rules based on self-awareness to adjust to organizational rules and standards. Thus it can be concluded that work discipline is someone's attitude of being aware, willing and ready to obey and comply with the rules and social norms that apply in his/her surrounding environment in order to change behavior as an effort to increase his/her awareness and willingness to work.

Employee discipline also shows the employee's respectful condition or attitude on rules and regulations. Thus, if the rules or provisions in a company are ignored or often violated, then it means that the employees have poor work discipline. Therefore, good work discipline will be a useful advantage, both for the company and for the employees themselves (Widya and Romat, 2017). According to Singodimejo in Sutrisno (2010), the indicators of work discipline are as follows:

1. Obeying rules of time regarding arrival time, departure time, and break time timely in accordance with the rules that apply in the organization.

2. Complying with organizational rules, basic rules on how to dress, and behave in work.

3. Obeying the rules of behavior in work, indicated by ways of doing tasks in accordance with position, duties, and responsibilities and ways of connecting with other work units.

4. Complying with other regulations in the company, the rules about what is allowed and what should not be done by employees in the company.

\section{Leadership}

A leader in an organization can create harmonious integration and encourage work passion of employees in order to achieve goals maximally. A leader is someone who uses authority, directs employees to work on his/her part of work to achieve organizational goals. A leader acts as a compiler of the direction of the company, communicates the strategy with employees, motivates employees and conducts long-term reviews (Rivai, 2009).

According to James M. Black in Samsudin (2010) leadership is someone's ability to convince and actuate other people to work together under his/her leadership as a team to achieve certain goals. It is in line with Pamudji (1993), in Susi and Yuli (2014), who defines leadership as an activity affecting other people to work together to achieve the desired goals.

Additionally, Thoha (2010) defines leadership as an activity to influence people to be directed to achieve organizational goals. Leadership includes the process of influencing in determining organizational goals, motivating employees' behavior to achieve goals, and influencing them to develop group and culture. Thus it can be con2cluded that leadership is a form of strategy or theory of leadership which is certainly done by a person who is usually called a leader.

Rivai (2012) says that a leader in implementing his/her leadership must be able to maturely carry out maturity on his/her institution or organization. Leadership is divided into five dimensions, namely: (1) The ability to foster good cooperation and relationship, (2) The ability in effectiveness, (3) Participatory leadership, (4) The ability to delegate tasks or time, (5) The ability to delegate tasks or authority 


\section{Organizational Culture}

According to Schein in Wirawan (2008) organizational culture is a pattern of basic assumptions that are found or developed by a group of people while they learn to solve problems, adjust to the external environment, and integrate with the internal environment. Robbins (2010) states that organizational culture comprises values, principles, traditions, and ways of working that are shared by members of the organization and influence the way they act. In most organizations, these shared values and practices have developed rapidly along with era development and really greatly influence how an organization is run.

Manahan (2004) argues that organizational culture is that a culture formed within an organization consists of the formation of dimensions of individual cultural interests, so as a basis for developing a positive organizational culture. So, based on some definitions above-mentioned, it can be concluded that organizational culture is a pattern of basic assumptions that contain values, beliefs, habits, norms and behavior shared by members of an organization in taking action and adjusting to their environment in achieving organizational goals.

According to Luthans (2006) there are several indicators of organizational culture, Rules of observed behavior, Norms, Dominant values, Philosophy and Rules

\section{Conceptual Framework}

One of the most important operative functions of Human Resource Management (HRM) is employee discipline because the better the employee discipline is, the higher the work performance can be achieved. Good discipline reflects the magnitude of one's responsibility for the tasks assigned to him/her. There are several factors that can affect the enforcement of employee discipline, including leadership and organizational culture.

Leadership refers to a leadership style or manner brought by a leader in influencing his/her followers. The development of employee discipline can be achieved when the leader can be a role model for the employees.

Employee discipline is consistent behavior that is done repeatedly so that a habitual pattern is formed. The patterned behavior and habits then form a culture. A behavior pattern or work habits that is accustomed in an organization is called organizational culture. Organizational culture is the values, principles, traditions and ways of working that are shared by members of an organization and influence the way they act.

The following is the conceptual framework of this study:

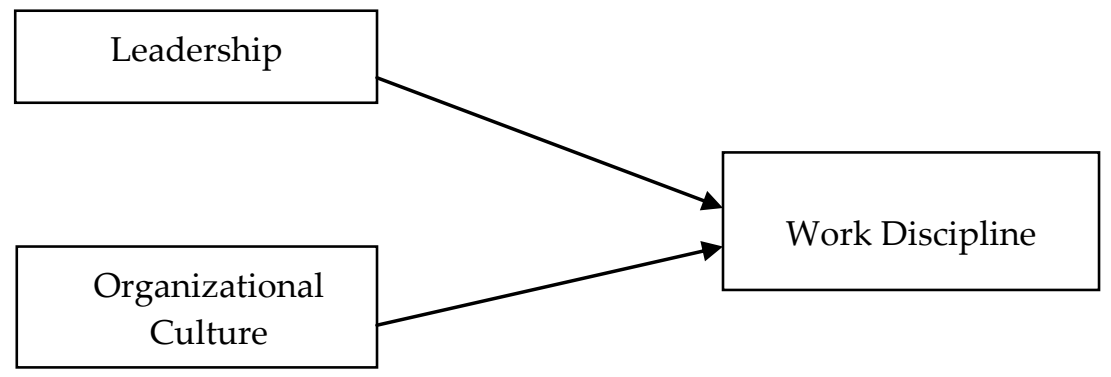

Figure 1 Conceptual framework

\section{Hypotheses}

The hypotheses of this study are:

H1. Leadership has positive and significant effect on work discipline of employees at the Regional Assets and Revenue Agency (BAPD) of West Pasaman regency.

H2. Organizational culture has positive and significant effect on work discipline of employees at the Regional Assets and Revenue Agency (BAPD) of West Pasaman regency. 


\section{Methods}

The purpose of this study is to test hypotheses using survey method. The data used were primary data collected through questionnaires. The population in this study was all employees at the Regional Assets and Revenue Agency (BAPD) of West Pasaman regency as many as 82 people. The sample was determined by total sampling technique, so the respondents in this study were 82 respondents.

Before the questionnaires were distributed, the instrument was tried-out first in order to obtain a valid and reliable instrument. After the data were obtained, then they were analyzed using multiple regression analysis through the SPSS program.

\section{Results and Discussion}

Before processing data with regression analysis, classical assumption tests were carried out, namely normality, multicollinearity, heteroscedasticity and linearity. After all assumptions were fulfilled, regression analysis could be done to test the hypotheses. In order to answer the hypotheses the data were analyzed by using multiple regression analysis technique through the SPSS program.

So, using the SPSS program version 16, regression coefficients obtained can be seen in the following table:

Table 2 Regression Coefficients

Coefficients $^{\mathrm{a}}$

\begin{tabular}{|c|c|c|c|c|c|c|}
\hline & \multirow[t]{2}{*}{ Model } & \multicolumn{2}{|c|}{ Unstandardized Coefficients } & \multirow{2}{*}{$\begin{array}{c}\begin{array}{c}\text { Standardized } \\
\text { Coefficients }\end{array} \\
\text { Beta }\end{array}$} & \multirow[t]{2}{*}{$\mathbf{t}$} & \multirow[t]{2}{*}{ Sig. } \\
\hline & & B & Std. Error & & & \\
\hline \multirow[t]{3}{*}{1} & (Constant) & .030 & .223 & & .133 & .894 \\
\hline & Leadership & .255 & .090 & .222 & 2.830 & .006 \\
\hline & Org_Culture & .772 & .086 & .704 & 8.976 & .000 \\
\hline
\end{tabular}

a. Dependent Variable: WD

Source : Primary data processing (2018)

Based on Table 2 above, it can be seen that the constant value was 0.030 meaning that if leadership and organizational culture were equal to zero (0), then work discipline of employees was equal to 0.030 . The regression coefficient of leadership was 0.255 with the significant value of $0.006<0.05$, meaning that there was positive and significant influence of leadership (X1) on work discipline of employees (Y). Then the first hypothesis was supported.

Furthermore, the regression coefficient of organizational culture was 0.772 , with the significant value of $0.000<0.05$. Thus there was positive and significant influence of organizational culture $(X 2)$ on work discipline of employees (Y) so that the second hypothesis was also supported. So, by referring to the table above, the regression equation was obtained as follows: $\mathrm{Y}=0.030+0.255 \mathrm{X} 1+$ $0.772 \times 2$.

Based on data processing, the coefficient of determination was also obtained. It can be seen in the following table:

Table 3. Coefficient of Determination $\left(\mathbf{R}^{2}\right)$

Model Summary

\begin{tabular}{|c|c|c|c|c|}
\hline Model & $\mathbf{R}$ & R Square & $\begin{array}{c}\text { Adjusted R } \\
\text { Square }\end{array}$ & Std. Error of the Estimate \\
\hline 1 & $.877^{a}$ & .768 & .762 & 27901 \\
\hline
\end{tabular}

a. Predictors: (Constant), Leadership, Org_culture

Source: Primary data processing (2018) 
Based on Table 3 above, adjusted R square was 0.762 . Therefore, it can be concluded that the contribution of leadership (Variable X1) and organizational culture (X2 Variable) to work discipline of employees (Variable Y) was $76.2 \%$. Mean while, the rest $23.8 \%$ was the contribution of other factors not included in this study to work discipline of employees.

Based on the results of data processing above, leadership had positive and significant effect on work discipline of employees. This means that the better a leader's leadership is, the more the improvement of employee discipline is achieved. A leader is said to be effective in his/her leadership if the employees are disciplined in carrying out the entire work process (Hasibuan, 2012). This result of the study is in line with the result of a study conducted by Alfonso (2017) that leadership had significant effect on work discipline and with the result of a study conducted by Jeli (2017) that leadership significantly influenced work discipline.

Then, this study also found that organizational culture had positive and significant effect on work discipline of employees. It means that when guidelines and rules that apply in the organization have clarity in sanctions for the violations, the members of the organization will try to act in accordance with the organization rules, in this case what constitutes the organizational culture. Robbins (2010) explains that organizational culture comprises values, principles, traditions and ways of working that are shared by members of the organization and influence the way they act.

This result of the study is in line with the resut of a study conducted by Mazayatul (2015) that there was positive and significant relationship between organizational culture and work discipline and with the result of a study conducted by M. Luhung and Benny (2016) that there was significant relationship between organizational culture and work discipline of employees at the production directorate of PT Krakatau Steel (Persero) Tbk Cilegon.

\section{Conclusions}

Based on the results of data processing, it can be concluded that: 1) there is a significant influence of leadership on work discipline of employees at the Regional Assets and Revenue Agency (BAPD) of West Pasaman regency; and 2) there is positive and significant influence of organizational culture on work discipline of employees at the Regional Assets and Revenue Agency (BAPD) of West Pasaman regency. This study show empirical evidence that to increase the work discipline of employees, it is necessary for company to improve the organizational culture and leardeship.

\section{References}

Alfonso F Nazar Nazar. (2017). Pengaruh Kepemimpinan Terhadap Disiplin Kerja Karyawan Pada Posmetro Mandau Duri. Jurnal Wira Ekonomi Mikroskil, 7 (2), 237-244.

Brahmarasari, Ida Ayu \& Siregar, Peniel. (2009). Pengaruh Budaya Organisasi, Kepemimpinan Situasional dan Pola Komunikasi terhadap Disiplin Kerja dan Kinerja Karyawan pada PT Central Proteinaprima Tbk. Jurnal Aplikasi Manajemen, 7 (1), ISSN: 1693-5241, 238-250.

Gouzali S. (2000). Manajemen Sumber Daya Manusia (Human Resource) Suatu Pendekatan Mikro, Jakarta: Djanbatan.

Hasibuan, Melayu. (2012). Manajemen Sumber Daya Manusia. Jakarta: PT Bumi Aksara.

Jeli Nata Liyas. (2017). Pengaruh Kepemimpinan Terhadap Disiplin Kerja Karyawan Pada Pt. Bank Syariah Mandiri. Jurnal Ekonomi dan Bisnis Islam. 2 (2), 121-129.

Luthans, Fred. (2006). Perilaku Organisasi. Yogyakarta : Andi

Manahan Tampubolon. (2004). Perilaku Keorganisasian. Jakarta: Ghalia Indonesia.

Mazayatul Mufrihah, Dr. Rizky Fauzan, SE, M.Si, Sulistiowati, SE, M.Si. (2015). Pengaruh Budaya Organisasi Dan Kepemimpinan Terhadap Disiplin Kerja Karyawan Pt. Telkomsel Pontianak. Jurnal Manajemen dan Bisnis, 3 (2).

Muhammad Luhung Pribadi, Benny Herlena. (2016). Peran Budaya Organisasi terhadap Disiplin Kerja Karyawan Direktorat Produksi PT Krakatau Steel (Persero) Tbk Cilegon. Jurnal Ilmiah Psikologi, 3 (2), 225-234. 
Rivai, Vertizal. (2006). Manajemen Sumber Daya Manusia Untuk Perusahaan Teori ke Praktek. Jakarta : Raja Grafindo Persada

Rivai, Veithzal. (2006). Kepemimpinan dan Perilaku Organisasi Edisi Kedua. Jakarta: PT. Raja Grafindo Persada.

Persada. (2005). Manajemen Sumber Daya Manusia untuk perusahaan. Jakarta: PT. Raja Grafindo

Robbins, Stephen. P. (2007). Terjemahan Prentice Hall Prinsip-Prinsip Prilaku Organisasi. Jakarta : Gramedia.

Robbins, Stephen. P. (2010). Manajemen. Jakarta : Erlangga

Siswanto Sastrohadiwirjo, B.S. (2002). Manajemen Tenaga Kerja Indonesia, Pendekatan Administratif dan Operasional. Jakarta: Bumi Aksara.

Susi Hendriani and Yuli Artati. (2014). Pengaruh Kepemimpinan, Budaya Organisasi Dan Disiplin Kerja Terhadap Kinerja Aparatur Sekretariat Daerah Kabupaten Kampar. Pekbis Jurnal, 6, (1), 14-25.

Sutrisno, Edy. (2010). Manajemen Sumber Daya Manusia. Jakarta : Kencana Prenada Media Group.

Thoha, Miftah. (2004). Kepemimpinan dalam Manajemen. Jakarta: Rajawali Press.

Umar, Husein. (2004). Riset Sumberdaya Manusia. Jakarta : PT Gramedia Pustaka Utama.

Widya Dwi Oktaviani \& Romat Saragih. (2017). Pengaruh Budaya Organisasi Terhadap Disiplin Kerja Karyawan Kantor Pusat Pt. Kereta Api Indonesia (Persero). e-Proceeding of Management, 4, (1), ISSN : 2355-9357, 687-692.

Wirawan. (2008). Budaya Organisasi dan Iklim Organisasi. Jakarta : Salemba Empat.

Wursanto, I.G. (2005). Manajemen Kepegawaian. Jakarta: Kanisius.

Zulganef. (2006). Permodelan Persamaan Struktur \& Aplikasinya Menggunakan Amos 5. Bandung: Penerbit Pustaka. 